billion as problem solvers. People are a country's biggest natural asset, and their engagement can bring about economic progress. Nearly two decades ago, I started an effort to provide widely accessible mobile-phone services in Bangladesh, leading to the creation of the company Grameenphone. A competitive multibillion-dollar telecommunications industry has since grown up there, based simply on products and services that increase people's productivity and income. In parallel, mobilephone technology has attracted billions of dollars in investment to other countries that lack drinking water, health care and electricity, such as in sub-Saharan Africa.

The money invested in mobile-phone infrastructure in poor countries did not come from state mineral wealth. Instead, individuals' ability to pay, stemming from their increased productivity, attracted investment. Entrepreneurs capitalized on this opportunity to provide a service. As economist Joseph Schumpeter noted in the 1930s, entrepreneurs - armed with ideas but not necessarily money - can rearrange the means of production to boost economic growth. In other words, empowered by tools and schemes that enhance productivity, the poor can tackle problems without relying on coordinated efforts by governments. It is a virtuous cycle: citizens advance their businesses and states collect more taxes, making them more accountable to the populace.
The supply of aid or a reliance on centralized mineral wealth destroys or prevents this link from emerging.

The Plundered Planet is right to highlight the importance of government accountability in addressing poverty and climate change. But it will be the dispersion of power, fuelled by entrepreneurship and innovation, that will ultimately empower individuals to create accountability and solve global problems.

Iqbal Quadir is professor of the practice of development and entrepreneurship and founder and director of the Legatum Center at the Massachusetts Institute of Technology, Cambridge, Massachusetts 02139, USA.

e-mail: iqbalquadir@mit.edu

\title{
Excavating the puzzle of the Paris zodiac
}

\author{
The Zodiac of Paris: How an Improbable \\ Controversy over an Ancient Egyptian \\ Artifact Provoked a Modern Debate Between \\ Religion and Science \\ by Jed Z. Buchwald and Diane Greco \\ Josefowicz \\ Princeton University Press: 2010. 376 pp. \\ $\$ 35.00, £ 24.95$
}

Compared with other ancient astronomical artefacts, the Egyptian carving known as the Dendera zodiac has been largely forgotten. Yet, two centuries ago, it was as celebrated as the just-discovered Rosetta Stone. The zodiac relief is now the subject of a groundbreaking study by historians of science Jed Buchwald and Diane Greco Josefowicz.

After Napoleon Bonaparte's invasion of Egypt in 1798, the elaborate panel was encountered on the ceiling of a temple at Dendera, north of ancient Thebes, now Luxor. The main part of the zodiac was removed by an enterprising, if unscrupulous, French engineer and shipped off to Paris in 1821, where it resides today at the Louvre Museum.

For decades after its discovery, the dating of the 'zodiac of Paris' was contested. Leading French scientists bitterly disagreed about the artefact's age on the basis of their astronomical calculations, including physicist Jean-Baptiste Biot and mathematician Joseph Fourier, who had accompanied Napoleon to Egypt. So too did other public figures, from sympathizers of the French revolution to supporters of Napoleon and his royalist successors.

Key to determining the zodiac's age was the historical position of stars in the depicted ancient sky. Fourier and others estimated that the object, and thus Egyptian civilization, was much older than the age permitted by the biblical account of human creation - as much as 15,000 years BC. Competing experts suggested that the zodiac was merely Greek or Roman, only 2,000 years old, post-dating the Egyptian pharaohs.

The zodiac became a cause célèbre for leftwing atheists and the rightwing devout. A vaudeville theatre production, Le Zodiaque de Paris, was staged in 1822 even though it had been censored by the French government. Actors played the signs of the zodiac accompanied by a chorus of wailing mummies to satirize the popular, official and scholarly reactions to the antique.

In the end, the Gordian knot was cut not by the quarrelling scientists but by a

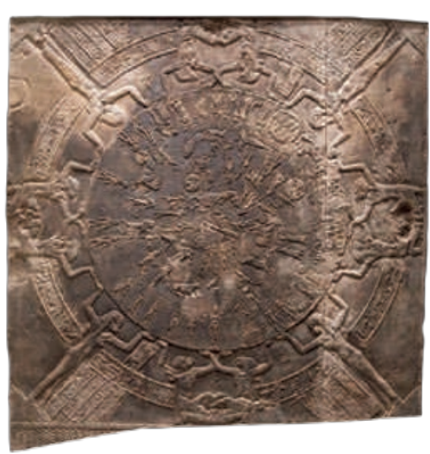

Dating this Egyptian artefact pitted science against religion. that the Roman dating was correct. The modern date is the first century $\mathrm{BC}$, which is in the time of Cleopatra, who is depicted in the temple. Yet the church's glee at this later date was not to last - other hieroglyphic inscriptions from the Valley of the Kings showed, to the satisfaction of Champollion, that Egyptian civilization went back at least 5,000 years. The zodiac did not support creationism after all.

Buchwald and Josefowicz excavated the story of the Paris zodiac by drawing on extensive primary French sources. They include crucial illustrations and colour in the background to the debate with lively accounts, for example, of Napoleon's savants in Egypt and life in Restoration Paris. But the challenge of integrating so much diverse and young philologist, Jean-François Champollion, who deciphered the Egyptian hieroglyphs in 1822-24. Studying a drawing of a surrounding part of the zodiac that had been left behind in the Dendera temple, he translated the meaning of a hieroglyphic cartouche within it as autocrator, a Graeco-Roman title. The Catholic Church was delighted that this agreed with their view and the Pope offered to make Champollion a cardinal - much to his disgust, given that he was an anti-royalist religious sceptic.

Ironically, the drawing was erroneous: when Champollion visited Egypt in 1828 he saw that the crucial sketch did not match the in situ Dendera cartouche, which was empty of hieroglyphs. But different evidence from the site confirmed unfamiliar material can overwhelm the reader.

The Zodiac of Paris provides an intriguing insight into a tumultuous era. The story was hardly a triumph for "the calculating savants" over "their pious antagonists", say Buchwald and Josefowicz - astronomy alone did not establish an age. Champollion eventually succeeded in understanding the zodiac because his decipherment embraced both the logic of science, the ambiguity of the humanities and the exigency of ancient Egyptian religion.

Andrew Robinson is a visiting fellow of Wolfson College, University of Cambridge, Cambridge CB3 9BB, UK. He is writing a biography of JeanFrançois Champollion.

e-mail:ar471@cam.ac.uk 